\title{
ANALISA SIMULASI MONTE CARLO DALAM MENENTUKAN PENDAPATAN PENJUALAN KERIPIK MACO BADARAI ISTIQOMAH PADANG SUMATERA BARAT
}

\author{
M. Hafizh 1), Rima Liana Gema ${ }^{2)}$ \\ ${ }^{1,2}$ Fakultas Ilmu Komputer, Universitas Putra Indonesia YPTK Padang, Jl. Raya Lubuk Begalung, Lubuk \\ Begalung Nan XX, Kec. Lubuk Begalung, Kota Padang, Sumatera Barat 25145 \\ email: ${ }^{1}$ hafizhmuhammad57@gmail.com, ${ }^{2}$ rimalianagema@upiyptk.ac.id
}

\begin{abstract}
The design of the system determines the number of sales items by using the monte carlo method at home-industry Istiqomah aims to predict the sale of each product for the next month and look for the gross income in each sold item. The sales system is designed to predict goods and search for dirty gains in each type of goods on a web-based store created using PHP and MYSQL as the database. With this system is expected to be used by the home-industry to simulate the sale of goods on the store, and can make it easier for home-industry owners to obtain information about the possibility that will happen to the sale of keripik maco products.
\end{abstract}

Keywords: Products , Monte Carlo, $P H P$ \& MySQL

Abstrak

Desain sistem ini menentukan jumlah penjualan barang-barang dengan menggunakan metode monte carlo di industri rumahan Istiqomah bertujuan untuk memprediksi penjualan setiap produk untuk bulan berikutnya dan mencari pendapatan kotor di setiap barang yang dijual. Sistem dirancang untuk memprediksi barang dan mencari keuntungan kotor di setiap jenis barang di toko yang dibuat menggunakan PHP dan MySQL sebagai databasenya. Dengan sistem ini dapat digunakan oleh industri rumahan untuk mensimulasikan penjualan barang di toko, dan dapat memudahkan pemilik industri rumahan untuk mendapatkan informasi tentang kemungkinan yang akan terjadi pada penjualan produk keripik maco.

Keywords: Produk, Monte Carlo, PHP \& MySQL

\section{PENDAHULUAN}

Home industri bagi sebagian orang adalah sebuah pilihan karena lapangan pekerjaan yang menjadi sangat menyempit. Namun, bagi sebagian orang memang sudah berniat membangun sejak lama karena menganggap home industri adalah sebuah pekerjaan yang menyenangkan, mudah, sekaligus menguntungkan dengan berbagai alasan (Haslinda, 2018).

Peningkatan perekonomian masyarakat tidak bisa hanya bertumpu pada sektor pertanian semata, namun juga memperhatikan sektor-sektor lain seperti industri, perdagangan, transportasi dan sebagainya. Sektor industri selama ini merupakan salah satu harapan dalam membangkitkan ekonomi masyarakat karena Sektor industri mempunyai pengaruh yang sangat kuat terhadap sektor-sektor lainnya. Bila sektor industri berkembang maka dapat diyakini sektor perdagangan juga akan turut meningkat (Syahdan, 2019).

Disamping pembangunan industri rumah tangga (homeindustry)/industri kecil ditujukan untuk meningkatkan dan memperbaiki struktur usaha industri kecil kearah yang lebih kuat dan mempunyai daya tumbuh dengan jalan meningkatkan peranan keterkaitan industri kecil dengan sektor industri lain. Oleh karena itu peran industri rumah tangga (homeindustry) yang dilakukan ibu rumah tangga di pedesaan perlu ditangani lebih seksama dan dirangsang pertumbuhannya dalam rangka memperluas kesempatan kerja maupun dalam rangka meningkatkan pendapatan masyarakat (Syahdan, 2019).

Faktor internal dalam pengembangan usaha kecil home industri, antara lain: Modal 
usaha yang kurang, pemasaran yang belum maksimal, manajemen usaha yang belum bagus, dan SDM yang kurang trampil. Sedangkan faktor eksternalnya yaitu : Pendanaan usaha kecil, Hibah bantuan modal dari pemerintah.(Zuhri, 2013)

Pesatnya persaingan bisnis saat ini menuntut pelaku bisnis untuk selalu mengikuti perkembangan pasar maupun keinginan dari pasar (Kusuma Dewi And Kesy Garside, 2016). biasanya home-industry Istiqomah memasarkan hasil industri bekerja sama dengan pengampas.

Makanan tradisional atau makanan lokal merupakan salah satu identitas suatu kelompok masyarakat yang sangat mudah untuk ditemukan dan mudah untuk dikenali. Setiap wilayah di Indonesia memiliki kekayaan kuliner yang menjadi ciri khas atau identitas daerah tersebut.(Purwaning Tyas, 2017)

Sumatera Barat terkenal dengan berbagai jenis kuliner yang mengandung banyak rempah, bumbu-bumbu dan mempunyai citarasa tinggi. Kuliner ini dapat berupa masakan ataupun kue-kue tradisional.(Wira $e t$ al., 2015) Salah satunya adalah keripik maco badarai.

Simulasi Monte Carlo merupakan simulasi probabilistik dimana suatu solusi dari suatu masalah diberikan berdasarkan proses randomisasi. Proses acak ini melibatkan suatu distribusi probabilitas dari variabel data yang dikumpulkan berdasarkan data masa lalu maupun distribusi probabilitas teoritis (Hutahaean, 2018)

Monte carlo dapat meniru suatu situasi dan keadaan secara sistematis sehingga dapat digunakan untuk proses pengambilan keputusan.(Muhajirin, 2013).

Dalam penelitian ini Pemodelan dan Simulasi Monte Carlo digunakan untuk membantu menentukan Perkiraan pendapatan penjualan produk keripik maco Badarai pada home-industry Istiqomah sehingga dapat digunakan sebagai pertimbangan dalam membuat strategi promosi pasar untuk penjualan yang efektif.

\section{METODE PENELITIAN}

Berikut merupakan kerangka penelitian yang akan dilakukan:

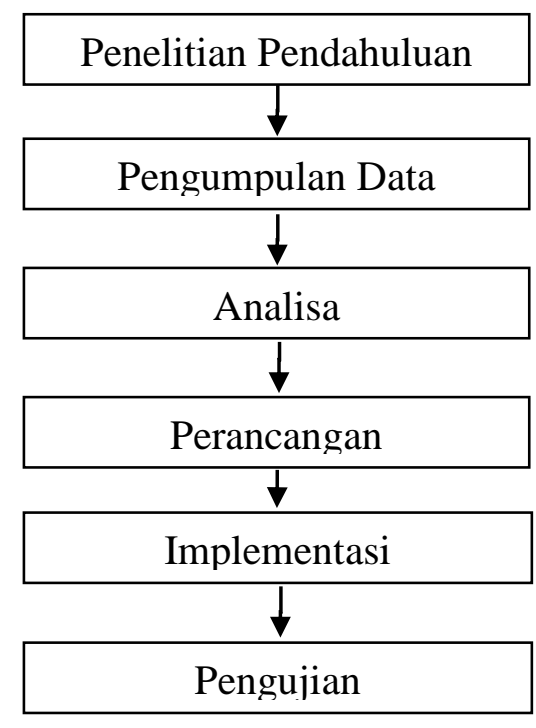

Gambar 1. Kerangka Penelitian

Dalam aktifitas produksi pada homeindustry keripik maco badarai Istiqomah ini, seringkali terjadi kesenjangan angka pendapatan setiap periodenya. Hal ini menyebabkan ketidakstabilan produksi seperti permintaan yang datang secara mendadak maupun stock barang yang terbatas yang menyebabkan aktifitas produksi tidak berjalan dengan baik

Penelitian ini dilakukan di home-industry Istiqomah yang beralamat di Jalan Sako ngalau no 13 Indarung, Kota Padang, Sumatera Barat. Data yang ada kemudian di Analisa agar dapat di pahami secara keseluruhan mengenai objek penelitian serta pemahaman secara teoritis maupun praktis mengenai teknik dan metode yang akan digunakan dalam penyelesaian masalahmasalah yang telah dirumuskan pada homeindustry Istiqomah.

Setelah melakukan analisa terhadap data dan sistem, selanjutnya juga melakukan perancangan terhadap sistem yang akan dibangun berdasarkan analisa sistem yang telah dilakukan. Adapun dalam melakukan perancangan sistem, menggunakan Unified Modeling Languange (UML) sebagai tools dalam mendeskripsikan alur kerja sistem. Salah satunya adalah Diagram use case yang merupakan pemodelan untuk kelakuan (behavior) sistem informasi yang akan dibuat. Use case mendeskripsikan sebuah interaksi antara satu atau lebih aktor, dan digunakan untuk mengetahui fungsi apa saja yang ada di dalam sebuah sistem informasi serta siapa saja yang berhak menggunakan fungsi-fungsi 
itu. Pada perancangan simulasi metode monte carlo di home-industry Istiqomah ini menggunakan satu aktor yang bisa mengoperasikan aplikasi yaitu manager. Adapun fasilitas yang diberikan untuk manager yaitu dapat mengoperasikan keseluruhan dari aplikasi tersebut.

Tahap Implementasi ke dalam aplikasi merupakan tahap memasukkan data-data yang telah diolah dan menerapkan model yang terbaik sehingga data tersebut siap untuk dioperasikan.

Setelah tahap implementasi selesai, penulis juga melakukan pengujian yang bertujuan untuk melakukan koreksi terhadap sistem yang telah dibangun berdasarkan tingkat efisiensi sistem sebagai solusi dalam pemecahan masalah-masalah yang telah dirumuskan. Pengujian aplikasi merupakan tahap akhir dalam melakukan testing, guna untuk mengetahui kesalahan dalam sistem. Pengujian dilakukan dengan melihat apakah aplikasi tersebut sudah berjalan dengan benar dan sesuai dengan perancangan yang dilakukan.

\section{HASIL DAN PEMBAHASAN}

Dalam simulasi Monte Carlo sebuah model dibangun berdasarkan sistem yang sebenarnya. Setiap variabel dalam model tersebut memiliki nilai yang memiliki probabilitas yang berbeda, yang ditunjukkan oleh distribusi probabilitas atau biasa disebut dengan probability distribution function (pdf) dari setiap variabel. Metode Monte Carlo mengsimulasikan sistem tersebut berulangulang kali, ratusan bahkan sampai ribuan kali tergantung sistem yang ditinjau, dengan cara memilih sebuah nilai random untuk setiap variabel dari distribusi probabilitasnya. Hasil yang didapatkan dari simulasi tersebut adalah sebuah distribusi probabilitas dari nilai sebuah sistem secara keseluruhan.(Fadjar, 2005)

Pengumpulan data dilakukan secara langsung observasi ke lapangan. Dalam hal penyelesaian dengan metode monte carlo yang akan dilakukan adalah menentukan penjualan beberapa barang yang banyak diminati oleh konsumen selama 6 bulan dan dilakukan pengolahan data pada tiap bulannya di home-industry Istiqomah sehingga dapat menghasilkan prediksi penjualan barang untu kedepannya. Pengumpulan data dari bulan
Agustus sampai Januari pada beberapa cabang toko, yaitu Toko HNH Mart Unand, Toko Citra Sungai Galang dan Toko Mahkota Air Tawar.

Pengelolaan data merupakan proses dalam melakukan simulasi Monte Carlo untuk menemukan hasil dan menjawab permasalahan yang ada.(Maddeppungeng, Ujianto and Fella, 2018)

Tabel 1. Data Harga Barang

\begin{tabular}{c|c|c}
\hline No & Nama Barang & Harga Jual \\
\hline 1 & Rakik Maco Badarai & Rp.15.000 \\
\hline 2 & Peyek Maco & Rp.15.000 \\
\hline 3 & Peyek Kacang & Rp.15.000 \\
\hline 4 & Peyek Kedelai & Rp.15.000 \\
\hline 5 & Rakik Maco Koin & Rp.15.000 \\
\hline 6 & Rakik Kacang Koin & Rp.15.000 \\
\hline
\end{tabular}

Harga barang di home-industry Istiqomah rata-rata di jual dengan harga Rp.15.000,-. Dengan data harga ini kita akan mencari distribusi penjualan seperti tabel di bawah ini :

Tabel 2. Toko HNH Mart Unand

\begin{tabular}{c|l|c|c|c|c}
\hline No & Bulan & $\begin{array}{c}\text { terj } \\
\text { ual }\end{array}$ & $\begin{array}{c}\text { Distribusi } \\
\text { Kemungkinan }\end{array}$ & $\begin{array}{c}\text { Distribusi } \\
\text { Kumulatif }\end{array}$ & Batas \\
\hline 1 & Agustus & 20 & $20 / 132=0,1515$ & 0,1515 & $0-0,1515$ \\
\hline 2 & September & 22 & $22 / 132=0,1667$ & 0,3182 & $0,1516-0,3182$ \\
\hline 3 & Oktober & 20 & $20 / 132=0,1515$ & 0,4697 & $0,3183-0,4697$ \\
\hline 4 & November & 25 & $25 / 132=0,1894$ & 0,6591 & $0,4698-0,6591$ \\
\hline 5 & Desember & 20 & $20 / 132=0,1515$ & 0,8106 & $0,6592-0,8106$ \\
\hline 6 & Januari & 25 & $25 / 132=0,1894$ & 1 & $0,8107-0,9997$ \\
\hline
\end{tabular}

Tabel diatas adalah data distribusi penjualan Toko HNH Mart Unand.

Tabel 3. Toko Citra Sungai Galang

\begin{tabular}{c|l|c|c|c|c}
\hline No & Bulan & $\begin{array}{c}\text { terj } \\
\text { ual }\end{array}$ & $\begin{array}{c}\text { Distribusi } \\
\text { Kemungkinan }\end{array}$ & $\begin{array}{c}\text { Distribusi } \\
\text { Kumulatif }\end{array}$ & Batas \\
\hline 1 & Agustus & 15 & $15 / 107=0,1402$ & 0,1402 & $0-0,1402$ \\
\hline 2 & September & 20 & $20 / 107=0,1869$ & 0,3271 & $0,1403-0,3271$ \\
\hline 3 & Oktober & 17 & $17 / 107=0,1589$ & 0,486 & $0,3272-0,486$ \\
\hline 4 & November & 20 & $20 / 107=0,1869$ & 0,6729 & $0,4861-0,6729$ \\
\hline 5 & Desember & 20 & $20 / 107=0,1869$ & 0,8598 & $0,673-0,8598$ \\
\hline 6 & Januari & 15 & $15 / 107=0,1402$ & 1 & $0,8599-1$ \\
\hline
\end{tabular}

Tabel diatas adalah data distribusi penjualan Toko Citra Sungai Galang.

Tabel 4. Toko Mahkota Air Tawar

\begin{tabular}{c|l|c|c|c|c}
\hline No & Bulan & $\begin{array}{c}\text { terju } \\
\text { al }\end{array}$ & $\begin{array}{c}\text { Distribusi } \\
\text { Kemungkinan }\end{array}$ & $\begin{array}{c}\text { Distribusi } \\
\text { Kumulatif }\end{array}$ & Batas \\
\hline 1 & Agustus & 35 & $35 / 180=0,1944$ & 0,1944 & $0-0,1944$ \\
\hline 2 & September & 25 & $25 / 180=0,1389$ & 0,3333 & $0,1945-0,3333$ \\
\hline 3 & Oktober & 30 & $30 / 180=0,1667$ & 0,5 & $0,3334-0,5$ \\
\hline 4 & November & 35 & $35 / 180=0,1944$ & 0,6944 & $0,5001-0,6944$ \\
\hline 5 & Desember & 35 & $35 / 180=0,1944$ & 0,8889 & $0,6945-0,8889$ \\
\hline 6 & Januari & 20 & $20 / 180=0,1111$ & 1 & $0,889-1$ \\
\hline
\end{tabular}


Tabel diatas adalah data distribusi penjualan Toko Mahkota Air Tawar .

Kemudian menentukan angka random yang berguna untuk memprediksi jumlah terjual dengan melihat posisi angka random pada batasan distribusi dari masing-masing cabang toko. Cara menentukan angka random dengan memanfaatkan aplikasi Microsoft Excel menggunakan fungsi randbetween yang ada pada microsoft excel $(=\operatorname{RAND}())$.

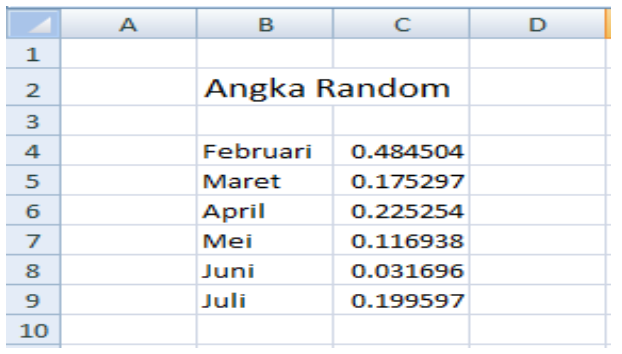

Gambar 2. Angka Random

Gambar di atas adalah angka random yang di bentuk dengan microsoft excel. Sehingga angka random yang akan di pakai bisa di lihat di tabel berikut ini :

Tabel 5. Angka Random

\begin{tabular}{l|l|l}
\hline No & Bulan & Random \\
\hline 1 & Februari & 0.484504 \\
\hline 2 & Maret & 0.175297 \\
\hline 3 & April & 0.225254 \\
\hline 4 & Mei & 0.116938 \\
\hline 5 & Juni & 0.031696 \\
\hline 6 & Juli & 0.199597 \\
\hline
\end{tabular}

Selanjutnya angka random pada tabel di atas berguna sebagai acuan prediksi penjualan.

Berikut prediksi penjualan dari setiap cabang toko untuk 6 bulan selanjutnya (Februari - Juli 2020) :

Tabel 6. Tabel Percobaan Di Toko HNH Mart Unand

\begin{tabular}{l|l|c|r}
\hline Bulan & $\begin{array}{l}\text { Angka } \\
\text { random }\end{array}$ & $\begin{array}{l}\text { Jumlah } \\
\text { terjual }\end{array}$ & Pendapatan \\
\hline Februari & 0.484504 & 25 & $\mathrm{Rp} .375 .000$ \\
\hline Maret & 0.175297 & 22 & $\mathrm{Rp} .330 .000$ \\
\hline April & 0.225254 & 22 & $\mathrm{Rp} .330 .000$ \\
\hline Mei & 0.116938 & 20 & $\mathrm{Rp} .300 .000$ \\
\hline Juni & 0.031696 & 20 & $\mathrm{Rp} .300 .000$ \\
\hline Juli & 0.199597 & 22 & $\mathrm{Rp} .330 .000$ \\
\hline \multicolumn{2}{c}{ Cross Income } & 131 & $\mathrm{Rp} .1 .965 .000$ \\
\hline
\end{tabular}

Tabel diatas adalah prediksi penjualan untuk bualan Februari sampai Juli 2020 di Toko HNH Mart Unand.

Tabel 7. Tabel Percobaan Di Toko Citra Sungai Galang

\begin{tabular}{|c|c|c|c|}
\hline Bulan & $\begin{array}{l}\text { Angka } \\
\text { random }\end{array}$ & $\begin{array}{l}\text { Jumlah } \\
\text { terjual }\end{array}$ & Pendapatan \\
\hline Februari & 0.484504 & 17 & Rp.255.000 \\
\hline Maret & 0.175297 & 20 & Rp.300.000 \\
\hline April & 0.225254 & 20 & Rp.300.000 \\
\hline Mei & 0.116938 & 15 & Rp. 225.000 \\
\hline Juni & 0.031696 & 15 & Rp.225.000 \\
\hline Juli & 0.199597 & 20 & Rp.300.000 \\
\hline \multicolumn{2}{|c|}{ Cross Income } & 107 & Rp.1.605.000 \\
\hline
\end{tabular}

Tabel diatas adalah prediksi penjualan untuk bualan Februari sampai Juli 2020 di Toko Citra Sungai Galang.

Tabel 8. Tabel Percobaan Di Toko Mahkota Air Tawar

\begin{tabular}{l|l|c|r}
\hline Bulan & $\begin{array}{l}\text { Angka } \\
\text { random }\end{array}$ & $\begin{array}{l}\text { Jumlah } \\
\text { terjual }\end{array}$ & Pendapatan \\
\hline Februari & 0.484504 & 30 & Rp.450.000 \\
\hline Maret & 0.175297 & 35 & Rp.525.000 \\
\hline April & 0.225254 & 25 & Rp.375.000 \\
\hline Mei & 0.116938 & 35 & Rp.525.000 \\
\hline Juni & 0.031696 & 35 & Rp.525.000 \\
\hline Juli & 0.199597 & 25 & Rp.375.000 \\
\hline \multicolumn{2}{c}{ Cross Income } & 185 & Rp.2.775.000 \\
\hline
\end{tabular}

Tabel diatas adalah prediksi penjualan untuk bualan Februari sampai Juli 2020 di Toko Mahkota Air Tawar.

Setelah membuat simulasi jumlah penjualan yang didapat dari serangkaian percobaan dari hasil pengambilan random number kemudian dapat disusun suatu tabel tiap pendapatan kotor penjualan (simulasi) pada setiap toko di home-industry Istiqomah untuk 6 bulan kedepan ( dapat dilihat pada tabel 9 di bawah ini.

Tabel 9. Pendapatan home-industry Istiqomah

\begin{tabular}{c|c|c}
\hline \multirow{2}{*}{ Nama Toko } & \multicolumn{2}{|c}{ Total (6 bulan) } \\
\cline { 2 - 3 } & Penjualan & Cross Income \\
\hline $\begin{array}{c}\text { HNH Mart } \\
\text { Unand }\end{array}$ & 131 & Rp.1.965.000 \\
\hline $\begin{array}{c}\text { Citra Sungai } \\
\text { Galang }\end{array}$ & 107 & Rp.1.605.000 \\
\hline $\begin{array}{c}\text { Mahkota Air } \\
\text { Tawar }\end{array}$ & 185 & Rp.2.775.000 \\
\hline Total & 423 & Rp.6.345.000 \\
\hline
\end{tabular}


Tabel diatas adalah prediksi penjualan untuk bualan Februari sampai Juli 2020 di home-industry Istiqomah.

Pengujian dan implementasi sistem bertujuan untuk mengidentifikasi apakah sistem yang dirancang telah sesuai dengan apa yang diinginkan dan sesuai dengan kebutuhan perusahaan. Dengan dilakukannya implementasi dan pengujian, peneliti dapat mengidentifikasi kualitas dari sistem yang dibangun tersebut. Tampilan website yaitu merupakan sub bab yang menjelaskan tentang proses dimulainya sampai program ini selesai dieksekusi point-point pada sub bab ini akan menjelaskan tentang bagaimana sebuah halaman dijalankan dan apa saja fungsi yang terdapat dari halaman tersebut.

Berikut interfacehalaman home hingga halaman laporan dan grafik :

1. Tampilan awal aplikasi

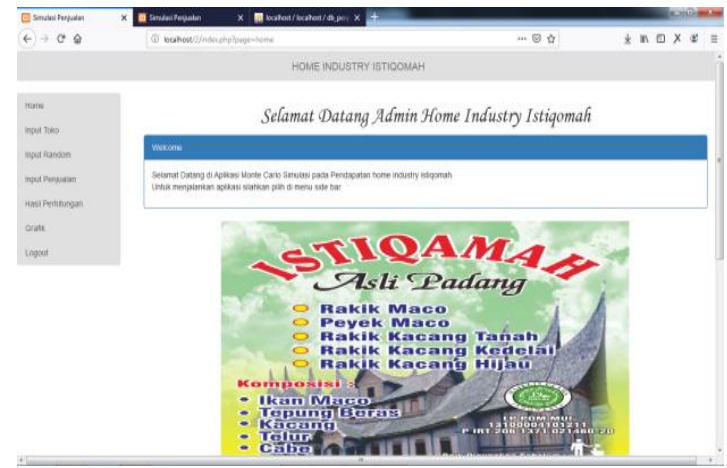

Gambar 3. Halaman Home

Halaman home di rancang sesuai karakter dan tema usaha home-industry Istiqomah.

2. Admin dapat menginputkan nilai random yang akan digunakan untuk proses data nantinya.

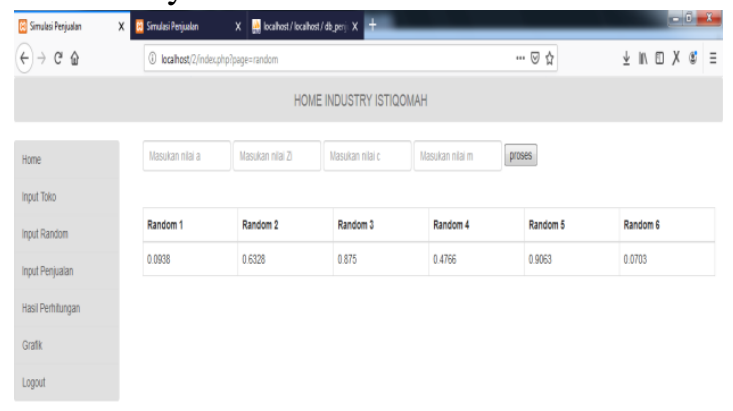

Gambar 4. Halaman Input Angka Random
Di halaman ini admin dapat memprediksi penjualan di bulan depan dengan menginputkan angka andom.

3. Tampilan Hasil.

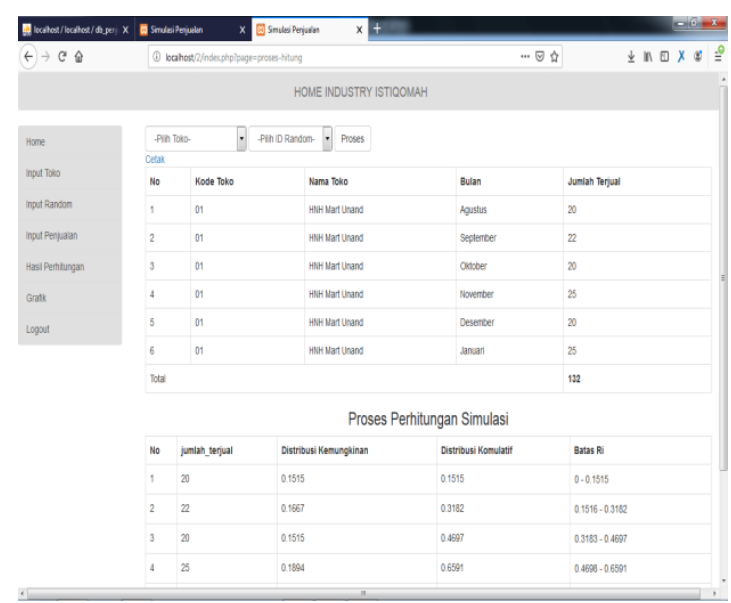

Gambar 5. Halaman Hasil Perhitungan

Pada halaman ini admin dapat memiih barang yang akan di proses dan akan menggunakan id random yang mana, kemudian klik proses.

\section{Grafik}

\section{Grafik Pendapatan}

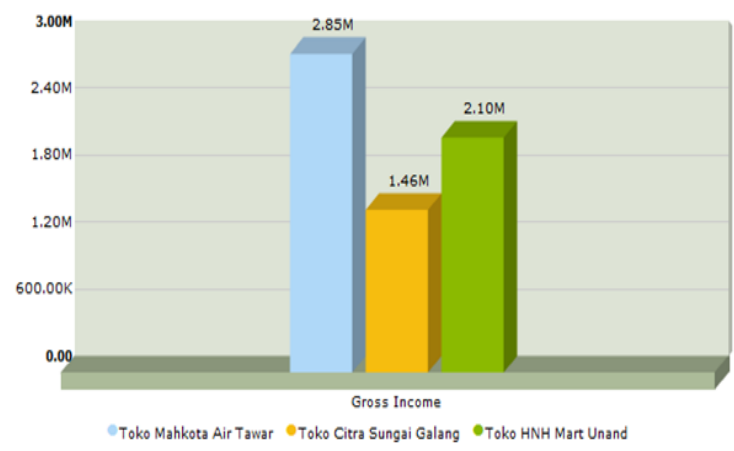

Gambar 6. Grafik

Grafik ini menunjukan pendapatan kotor dari setiap produk sehingga pemilik toko atau admin dapat melihat produk mana yang lebih tinggi pendapatannya.

\section{SIMPULAN}

Berdasarkan dari prose spembangunan sistem yang telah dilakukan oleh peneliti, peneliti menarik kesimpulan bahwa dengan menggunakan aplikasi yang dirancang 
pemilik toko home-industry Istiqomah dapat mengetahui keuntungan dengan melihat hasil laporan pendapatan atau barang yg terjual di bantu dengan adanya sistem penjualan pemilik dapat dengan mudah membandingkan pendapatan pada setiap toko yang menjual produk keripik maco badarai istiqomah melalui hasil perhitungan dan laporan yang terdapat pada aplikasi ini. pemilik homeindustry Istiqomah juga dapat mengetahui tingkat minat konsumen dengan melihat hasil input data yang didalamnya terdapat jumlah barang yang terjual di setiap periodenya. Dari sana Pemilik home-industry dapat meningkat kualitas produk dari setiap jenis produk yang di buat.

\section{UCAPAN TERIMAKASIH}

Dalam menyelesaikan Penelitian ini kami mengucapkan terima kasihkepada Universitas Putra Indonesia YPTK Padang dan home-industry Istiqomah yang telah bersedia memberikan data-data yang dibutuhkan, sehingga penelitian ini dapat menyelesaikan.

\section{DAFTAR PUSTAKA}

Fadjar, A. (2005) 'Aplikasi Simulasi Monte Carlo Dalam Estimasi Biaya Proyek', SMARTek.

Haslinda (2018) 'Perilaku Sosial Ekonomi pada Usaha Home Industri Tahu di Kecamatan Tomoni Kabupaten Luwu Timur', Proceeding Series: On Islamic Studies, Sharia and Law, Vol. 1, p. 9. Available at: http://eprints.unm.ac.id/id/eprint/1080 9.

\begin{tabular}{crrr} 
Hutahaean, H. D. & $(2018)$ & 'ANALISA \\
SIMULASI & MONTE & CARLO \\
UNTUK & MEMPREDIKSI \\
TINGKAT & KEHADIRAN \\
MAHASISWA & \multicolumn{2}{c}{ DALAM } \\
PERKULIAHAN (Studi Kasus : & STMIK PELITA NUSANTARA)', \\
Sournal Of Informatic Pelita \\
Nusantara.
\end{tabular}

KUSUMA DEWI, S. and KESY GARSIDE, A. (2016) 'PERANCANGAN WEbSITE SEBAGAI MEDIA PROMOSI DAN PENJUALAN PADA HOME INDUSTrY ABON',
Jurnal Teknik Industri. doi: 10.22219/jtiumm.vol15.no2.170-181.

Maddeppungeng, A., Ujianto, R. and Fella, M. (2018) 'PENERAPAN METODE SIMULASI MONTE CARLO TERHADAP RISIKO FINANSIAL PROYEK KONSTRUKSI (Studi Kasus: Apartemen X di Cipulir)', JURNAL FONDASI. doi: 10.36055/jft.v7i2.4070.

Muhajirin, S. D. (2013) 'PENERAPAN METODE MONTE CARLO DALAM PEMBUATAN PERANGKAT LUNAK MANAJEMEN ASET PADA PT. CAPRA KARYA', Jurnal Inspiration, 3(2). doi: http://dx.doi.org/10.35585/inspir.v3i2 .37 .

Purwaning Tyas, A. S. (2017) 'Identifikasi Kuliner Lokal Indonesia dalam Pembelajaran Bahasa Inggris', Jurnal Pariwisata Terapan. doi: 10.22146/jpt.24970.

Syahdan, S. (2019) 'Peran Industri Rumah Tangga (Home Industry) pada Usaha Kerupuk Terigu terhadap Pendapatan Keluarga di Kecamatan Sakra Kabupaten Lombok Timur', MANAZHIM. doi: 10.36088/manazhim.v1i1.136.

Wira, V. et al. (2015) 'Profil industri rumah tangga rakik di kecamatan pauh kota padang', Jurnal Akuntansi \& Manajemen, 10, p. 2.

Zuhri, S. (2013) 'Analisis Pengembangan Usaha Kecil home Industri Sangkar Ayam Dalam Rangka Pengentasan Kemiskinan', Manajemen dan Akuntansi. 